\title{
The Therapeutic Potential of the Anticancer Activity of Fucoidan: Current Advances and Hurdles
}

\author{
Jun-O. Jin ${ }^{1,2,3, *,+}$, Pallavi Singh Chauhan ${ }^{4,+}$, Ananta Prasad Arukha ${ }^{5}$, Vishal Chavda ${ }^{6}$, Anuj Dubey ${ }^{7}$ and \\ Dhananjay Yadav $2, *$ (D)
}

check for

updates

Citation: Jin, J.-O.; Chauhan, P.S.; Arukha, A.P.; Chavda, V.; Dubey, A.; Yadav, D. The Therapeutic Potential of the Anticancer Activity of

Fucoidan: Current Advances and Hurdles. Mar. Drugs 2021, 19, 265. https://doi.org/10.3390/md19050265

Received: 11 March 2021

Accepted: 4 May 2021

Published: 10 May 2021

Publisher's Note: MDPI stays neutral with regard to jurisdictional claims in published maps and institutional affiliations.

Copyright: (c) 2021 by the authors. Licensee MDPI, Basel, Switzerland. This article is an open access article distributed under the terms and conditions of the Creative Commons Attribution (CC BY) license (https:/ / creativecommons.org/licenses/by/ $4.0 /)$.
1 Shanghai Public Health Clinical Center \& Institutes of Biomedical Sciences, Shanghai Medical College, Fudan University, Shanghai 201508, China

2 Department of Medical Biotechnology, Yeungnam University, Gyeongsan 38541, Korea

3 Research Institute of Cell Culture, Yeungnam University, Gyeongsan 38541, Korea

4 Amity Institute of Biotechnology, Amity University Madhya Pradesh, Gwalior 474005, India; pschauhan@gwa.amity.edu

5 Comparative Diagnostic and Population Medicine, College of Veterinary Medicine, University of Florida, Gainesville, FL 32608, USA; ananta.arukhaa@gmail.com

6 Division of Anaesthesia, Sardar Women's Hospital, Ahmedabad 380004, Gujarat, India; chavdavishal2@gmail.com

7 Department of Chemistry, ITM Group of Institutions, Gwalior 475005, India; anujdubey.mail@gmail.com

* Correspondence: jinjo@yu.ac.kr (J.-O.J.); dhanyadav16481@gmail.com (D.Y.)

+ These authors contributed equally to this work.

\begin{abstract}
Several types of cancers share cellular and molecular behaviors. Although many chemotherapy drugs have been designed to weaken the defenses of cancer cells, these drugs may also have cytotoxic effects on healthy tissues. Fucoidan, a sulfated fucose-based polysaccharide from brown algae, has gained much attention as an antitumor drug owing to its anticancer effects against multiple cancer types. Among the anticancer mechanisms of fucoidan are cell cycle arrest, apoptosis evocation, and stimulation of cytotoxic natural killer cells and macrophages. Fucoidan also protects against toxicity associated with chemotherapeutic drugs and radiation-induced damage. The synergistic effect of fucoidan with existing anticancer drugs has prompted researchers to explore its therapeutic potential. This review compiles the mechanisms through which fucoidan slows tumor growth, kills cancer cells, and interacts with cancer chemotherapy drugs. The obstacles involved in developing fucoidan as an anticancer agent are also discussed in this review.
\end{abstract}

Keywords: anticancer activity; fucoidan; tumor growth; cytotoxic effects; brown algae

\section{Introduction}

Genetic engineering and biopharmaceutical research conducted on polysaccharide biomacromolecules has revealed that acidic polysaccharides from aquatic sources act as curative agents. In this respect, fucoidan, a complex polysaccharide found in certain species of brown seaweed, has shown promising results [1-3]. Brown macroalgae, such as gulfweed, are a class of seawater plants that are extensively dispersed in numerous cold marine regions. Fucoidan is derived from the cell wall matrix of brown algae and are rich in active substances, such as polysaccharides, terpenoids, proteins, polyphenols, sterols, multi-ring sulfur compounds, macrolides, and trace elements [4]. To extricate fucoidan from seaweeds, dilute acid, water, or alkali is generally used; however, these techniques require more time and larger quantities of reagents. As such, researchers have upgraded the conventional extraction techniques and standardized new techniques. The water molecules in cells are vibrated by microwave or ultrasound, causing the cells to split and thus enhance the coherence of conventional water extraction techniques. Enzyme-assisted extraction techniques have a high degree of coherence and precision and use enzymes to break down the cell wall [5]. 
The therapeutic benefits of fucoidan have attracted the interest of many researchers over the last 5-10 years. In many countries, such as Japan, China, and South Korea, brown seaweed is established as a local cuisine. Fucoidan is a complex sulfated heteropolysaccharide [6] comprising L-fucose-4-sulfate monosaccharides that consist of L-fucose and sulfate groups. Other monosaccharides such as uronic acid, galactose, xylose, mannose, rhamnose, glucose, arabinose, and xylose are also present. The two chain-forming structures of fucoidan are $(1 \rightarrow 3)$ - $\alpha$-L-fucopyranose and $\alpha$-L-fucopyranose linked by $(1 \rightarrow 3)$ and $(1 \rightarrow 4)$ [7]. Single and double substitutions in fucoidan occur at the C-2 and C-3 positions [8]. The factors on which the structure and composition of fucoidan depend are the species of seaweed, geographic site of collection, time of harvest, anatomical regions, and extraction procedures. Fucoidans are mined from other natural resources through the use of microwaves, hot water baths, or acid baths [9]. Extraction methods determine the bioactivity and molecular weight (Mw) of fucoidan, which may vary from 10,000-100,000 Da. Fucoidan is nontoxic, nonirritating, bioactive, and has many therapeutic applications [10]; thus, it has become a popular research topic in terms of its separation, purification, production, structural analysis, bioactivity, and oral absorption. This review highlights the bioactivity and the recently discovered cellular functions of fucoidan. Fucoidan is also important for the regulation of glucose and cholesterol metabolism [11]. Several studies have shown its antiviral, immunoregulatory, antitumor, anticoagulant, antithrombotic, anti-inflammatory, and antioxidant effects [12,13]. Important biological activities of fucoidan have been discovered by investigating these pathways. Furthermore, sulfate groups, Mw, natural sources, and extraction methods are some of the factors affecting the bioactivity of fucoidan [7]. In this review, we attempt to elucidate the mechanisms through which fucoidan hampers tumor growth and cancer cell activity and interacts with chemotherapeutic drugs and also discuss the hurdles faced in the anticancer application of fucoidan.

\subsection{Fucoidan}

Fucoidan was first sourced from species of brown algae, namely Laminaria digitata, Ascophyllum nodosum, and Fucus vesiculosus, in 1913. It is an extremely hygroscopic and negatively charged polysaccharide. The leaves of L. digitata, A. nodosum, Macrocystis pyrifera, and F. vesiculosus contain high levels of fucoidan [14]. Fucoidan is soluble in both water and acids, and recent studies have shown that it is beneficial in protecting against liver damage and urinary system failure $[15,16]$.

\subsection{Sources of Fucoidan}

Sea cucumbers and brown algae are marine sources that harbor the sulfated polysaccharide fucoidan. Chorda filum, Hizikia fusiforme, Ascophyllum nodosum, Fucus evanescens, Fucus serratus, Fucus distichus, Fucus vesiculosus, Sargassum stenophyllum, Caulerpa racemosa, Kjellmaniella crassifolia, Dictyota menstrualis, Analipus japonicus, Padina gymnospora, and Laminaria hyperborea are some of the algae and invertebrates containing fucoidan, among which the content, type, and preferred method of extraction vary [17].

\subsection{Structure of Fucoidan}

Fucoidan, a fucose-enriched sulfated polysaccharide, is mainly extracted from the extracellular matrix of brown algae. In different species of brown algae, fucoidan consists of L-fucose and sulfate groups and one or more small xylose, galactose, mannose, rhamnose, glucuronic acid, glucose, arabinose, and acetyl groups [18]. Galactofucan fucoidan is a monosaccharide composed of galactose and fucose, similar to rhamnofucan (rhamnose and fucose) and rhamnogalactofucan (rhamnose, galactose, and fucose). Variation among the different seaweeds can be observed by examining the structure of fucoidan. However, fucoidan usually has two types of homofucoses; type one (I) comprises repeated units of $(1 \rightarrow 3)-1$-fucopyranose, and the second type (II) encompasses alternating and recurring 
units of $(1 \rightarrow 3)$ - and $(1 \rightarrow 4)$-1-fucopyranose $[19,20]$. The chemical structure of fucoidan is shown in Figure 1.

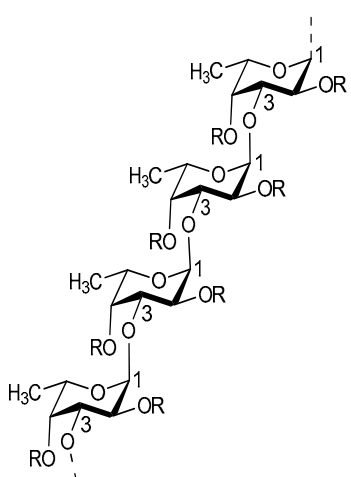

(A)

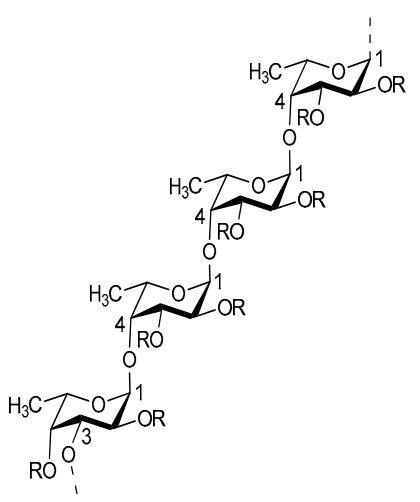

(B)

Figure 1. The chemical structures of fucoidan of two different backbones $(\mathbf{A}, \mathbf{B})$. R shows the potential places for attachment of carbohydrate ( $\alpha$-L-fucopyranose and $\alpha$-D-glucuronic acid) and noncarbohydrate (sulfate and acetyl groups) substituents, adapted from [21].

\subsection{Dosage and Course of Administration}

The dosage of fucoidan varies greatly between different studies because of the different sources and decontamination techniques that are used [22]. Alwarsamy et al. found that fucoidan arrests $50 \%$ of cell reproduction in A549 lung cancer cells after $48 \mathrm{~h}$ of treatment with $100 \mu \mathrm{g} / \mathrm{mL}$ fucoidan [23]. The antitumor activity of fucoidan was studied in C57 BL/6 mice with Lewis lung adenocarcinoma. The results showed that there was no considerable impact on tumors when mice were injected with $25 \mathrm{mg} / \mathrm{kg}$ fucoidan. Meanwhile, mice could endure a repeated dosage of $10 \mathrm{mg} / \mathrm{kg}$ of fucoidan, and the drug revealed remarkable antitumor (inhibited tumor growth by $33 \%$ ) and antimetastatic activities (29\% reduction) [24]. Intraperitoneal injection and/or administration of fucoidan through food, gavages, subcutaneous injection, and intravenous injection have also been thoroughly researched [25-29].

\section{Anticancer Potential of Fucoidan: Insights from Recent Studies}

Cancer is a composite disease with unprecedented cell growth. Factors such as sepsis, smoking, occupational exposure, environmental pollution, obstructive diet, and hereditary components influence the complex procedure of the growth and development of the human body [30]. Tumor cell propagation and maintenance are generally associated with uncommon subcellular signal transduction and the uninterrupted sustenance of cellular growth [31]. For example, because of its participation in numerous cellular functions involving mRNA, cell cycle regulation, gene copy, apoptosis, autophagy, and metabolism, the P13K-AKT-mTOR signaling pathway is often engaged. Surgery, radiotherapy, and chemotherapy are the main dependable lines of cancer treatment [32-34]. However, the side effects of these treatments are significant, and the therapeutic outcomes are limited. It has been observed that a few of the inherent intrinsic signaling pathways can hinder or slow carcinogenesis at different phases and they exhibit characteristics such as explicit targeting, reduced cytotoxicity, and the induction of cancer cell apoptosis [35-38].

Fucoidan has been used as a medicinal food supplement in Asia owing to its medicinal function and anticancer ability $[39,40]$, which has been extensively studied since the 1980s [25,41]. Several studies have shown that fucoidan can act against cancer through cell cycle arrest, thereby hindering angiogenesis by inducing apoptosis or activating natural killer (NK) cells or macrophages [42,43]. Additionally, fucoidan has countless superior biological activities, which include anti-inflammatory, antioxidant, anticlotting, antithrombotic, antiviral, anti-angiogenesis, and anti-Helicobacter pylori activities [6,21,44-47]. Natural 
extracts are associated with high biological activity, a wide range of sources, low drug resistance, and a low number of side effects compared with chemically synthesized drugs; therefore, natural extracts are actively being researched as novel antitumor drugs or as complementary drugs in combination with conventional antitumor drugs [48]. Fucoidan has a strong natural antioxidant activity and can substantially scavenge surplus free radicals. In one study, the low-molecular-weight fucoidan (LMWF) was processed and the fractions DF1, DF2, and DF3 were obtained [49], all of which showed superoxide anion radical scavenging activity. It has been seen that the antiviral action of fucoidan is strongly related to its sulfate content [50]. Its antiviral activity increases with an increase in the mass fraction of the constituting sulfate groups [51]. Nonetheless, the molecular weight and structure of the fucoidan acquired via various extraction techniques are distinct, and these factors have unquestionable effects on fucoidan's biological activities [6,17].

\subsection{Fucoidan Modulates Apoptosis and Cell Cycle}

Necessary processes, such as embryonic development and homeostasis in organisms, are maintained by apoptosis, also known as programmed cell death. This section highlights how malignant or cancer cells undergo apoptosis in multiple ways after stimulation with fucoidan; these multiple pathways include the caspase system, cell cycle checkpoints, and internal and external pathways [52]. At a concentration of $1.0 \mathrm{mg} / \mathrm{mL}$, fucoidan derived from C. okamuranus increased the G0/G1-phase population fraction of Huh7 hepatocarcinoma cells. This mechanism was followed by a decrease in the S-phase fraction, suggesting that fucoidan may cause cell cycle arrest in the G0/G1 phase [53]. Zhang et al. demonstrated that when high-molecular-weight fucoidan was extracted from Cladosiphon novae-caledoniae kylin and then digested with glysidases, it produced LMWF. LMWF consists of a low-molecular-weight digested fraction (72\%) and an undigested fraction of less than $28 \%$. LMWF consists mainly of fucose, xylose, and mannose. Furthermore, LMWF complexed with tamoxifen, cisplatin, or paclitaxel shows cell growth inhibition, cellular apoptosis, and arrest of the cell cycle in the human breast cancer cell line MCF-7 / MDA-MB231. The study revealed that in breast cancer cells, phosphorylation of different proteins, elevation the reactive oxygen species (ROS) levels, and reduced glutathione (GSH) levels were all crucial in cancer cell apoptosis [54].

Researchers conducted comparative apoptosis studies and found that type II fucoidan isolated from F. vesiculosus showed similar apoptosis induction activities through caspase-8 and -9 activation in MCF-7 and HeLa cells to the low-molecular-weight type I fucoidan derivatives [55-58]. Fucoidan is a potential adjuvant for treating melanoma. Although therapeutic strategies involving combined therapies exist, their efficacy depends on several factors, including the overall health of the patient, the stage of metastases, and the melanoma location [59]. However, the effectiveness of these treatments may be reduced slightly because of the progression of new resistance mechanisms. Therefore, new therapeutic targets for melanoma are urgently needed. For example, $F$. vesiculosus fucoidan showed inhibitory effects on cell proliferation and apoptosis induction in B16 melanoma cells [60]. Fucoidan inhibits tumor cells by activating apoptosis and is therefore a potential therapeutic agent. Several studies have been conducted to develop fucoidan as an anticancer therapeutic by combining it with other anticancer agents [61-63]. However, more cancer studies are needed, particularly considering the discrepancies in the results of animal studies and human clinical trials, which can be caused due to the way the human body absorbs and processes fucoidan [52,64-66]. The next section briefly describes the known anticancer mechanisms of fucoidan.

\subsection{Possible Pathways Involved in the Anticancer Action of Fucoidan}

The anticancer mechanism of fucoidan has been shown to primarily include four elements, according to previous reports:

- Inhibition of normal mitosis and cell cycle regulation: 
Fucoidan reduces cancer cell proliferation by inhibiting normal mitosis and cell cycle regulation [67]. When fucoidan was injected into C57 mice with transplanted Lewis lung adenocarcinoma cells, it was observed that the number of tumor masses and lung metastases was significantly lower than that in cyclophosphamide treated mice, indicating that metastasis and tumor cell growth are effectively inhibited by fucoidan [24].

- Activation of tumor cell apoptosis signals:

Fucoidan leads to the activation of tumor cell apoptosis signals, leading to anticancer effects [68]. HT-29 and HCT116 human colon cancer cells were cocultured with fucoidan extracted from Fucus vesiculosus. The results showed that fucoidan induced caspase-3, -7 , -8 , and -9 activation, chromatin condensation, and poly (ADP-ribose) polymerase (PARP) cleavage [69].

- Inhibition of vascular endothelial growth factor (VEGF) formation:

VEGF formation can be inhibited by fucoidan, which leads to angiogenesis suppression, interruption in the supply of nutrients and oxygen to the tumor, tumor volume reduction, and inhibition of the spread of cancer cells [70,71]. Fucoidan was administered to mice implanted with Lewis lung cancer cells, and the results showed reduced VEGF levels in serum and lung tissue compared to those in non-FUCs [7]. Fucoidan or fucoidan persulfate can inhibit VEGF165 mitosis and chemotaxis in human umbilical vein endothelial cells by inhibiting VEGF165 at cell surface receptors [71,72]. Fucoidan also inhibits cell-induced neovascularization of human prostate cancer (DU-145) as observed in mice with transplanted B16 melanoma cells. Thus, these results showed that the antitumor activity of fucoidan is related to its anti-angiogenic effect [73,74].

- Stimulation of NK cells and T lymphocytes:

Fucoidan activates the immune system by elevating the actions of NK cells and T lymphocytes to target cancer cells. Mice transplanted with NB4 (acute promyelocytic leukemia cells) were fed fucoidan, which led to an increased killing activity of cancer cells by NK cells [75]. Table 1 summarizes the in-vitro effect of fucoidan isolated from various sources of marine algae on cancer cells.

Table 1. Effect of fucoidan on cancer cells in-vitro.

\begin{tabular}{|c|c|c|c|c|c|}
\hline $\begin{array}{l}\text { Effect of } \\
\text { Fucoidan }\end{array}$ & Cell Type & Fucoidan Source & Study Findings & Mechanism of Action & Ref. \\
\hline \multirow{3}{*}{ Colon cancer cells } & DLD-1 & Saccharina cichorioides & $\begin{array}{l}\text { EGF receptor binding inhibition with } \\
\text { EGF and colony formation inhibition }\end{array}$ & Inhibits cell proliferation & [76] \\
\hline & $\begin{array}{l}\text { HT-29 } \\
\text { HCT-116 }\end{array}$ & Fucus vesiculosus & $\begin{array}{c}\text { Downregulating the PI3K-Akt-mTOR } \\
\text { pathway, } \\
\text { Activation of Caspase- } 8,9,7,3 \\
\text { activation, } \\
\uparrow \text { PARP, Bak, Bid, Fas, } \\
\downarrow \text { Mcl- } 1 \text {, survivin, XIAP }\end{array}$ & Induces cell apoptosis & {$[69,77]$} \\
\hline & $\begin{array}{l}\text { WiDr } \\
\text { LoVo }\end{array}$ & Undaria pinnatifida & $\begin{array}{l}\text { Less cytotoxic and can be used as } \\
\text { functional food in cancer treatment }\end{array}$ & $\begin{array}{l}\text { Suppresses cell } \\
\text { proliferation }\end{array}$ & [56] \\
\hline \multirow{3}{*}{ Breast cancer cells } & MCF-7 & $\begin{array}{l}\text { Fucus vesiculosus/ } \\
\text { Cladosiphon } \\
\text { okamuranus }\end{array}$ & $\begin{array}{c}\text { PARP cleavage } \\
\text { Caspase- } 7,8,9 \uparrow \\
\text { Cytochrome C, Bax, Bid } \uparrow \\
\text { Modulating E-cadherin and MMP-9 } \\
\text { expression inhibition of tumor cell } \\
\text { migration }\end{array}$ & $\begin{array}{l}\text { Induces tumor cell } \\
\text { apoptosis and inhibit } \\
\text { proliferation }\end{array}$ & {$[78,79]$} \\
\hline & $\mathrm{T}-47 \mathrm{D}$ & Saccharina japonica & $\begin{array}{l}\text { Cytotoxicity against human breast } \\
\text { cancer }\end{array}$ & $\begin{array}{l}\text { Inhibits cell proliferation } \\
\text { and colony formation }\end{array}$ & [80] \\
\hline & MDA-MB-231 & Fucus vesiculosus & $\begin{array}{l}\text { Activation of caspases and } \\
\text { mitochondrial dysfunction along with } \\
\text { altering } \mathrm{Ca}(2+) \text { homeostasis, } \\
\text { cytochrome c release }\end{array}$ & Cancer cell death & [81] \\
\hline
\end{tabular}


Table 1. Cont.

\begin{tabular}{|c|c|c|c|c|c|}
\hline $\begin{array}{l}\text { Effect of } \\
\text { Fucoidan }\end{array}$ & Cell Type & Fucoidan Source & Study Findings & Mechanism of Action & Ref. \\
\hline \multirow{3}{*}{$\begin{array}{l}\text { Hepatoma } \\
\text { carcinoma cells }\end{array}$} & $\begin{array}{l}\text { BEL-7402 } \\
\text { LM3 }\end{array}$ & Fucus vesiculosus & $\begin{array}{c}\text { Pathways targeted were p38 } \\
\text { MAPK/ERK pathways, PI3K/Akt, and } \\
\text { upstream kinases. Alteration in } \\
\text { phosphorylation of p38 MAPK and ERK }\end{array}$ & $\begin{array}{l}\text { Promotes apoptosis, } \\
\text { inhibits cell proliferation }\end{array}$ & [82] \\
\hline & SMMC-7721 & Undaria pinnatifida & $\begin{array}{c}\text { Livin, XIAP mRNA } \downarrow \\
\text { Caspase- } 3,-8,-9 \uparrow \\
\text { Bax-to-Bcl- } 2 \text { ratio } \uparrow \\
\text { Cytochrome C } \uparrow \\
\text { Quantity of mitochondria } \downarrow \\
\text { ROS } \uparrow \\
\text { Depolarization of the MMP }\end{array}$ & Induces cell apoptosis & [83] \\
\hline & $\begin{array}{l}\text { Huh-7 } \\
\text { SNU-761 } \\
\text { SNU-3085 }\end{array}$ & Fucus vesiculosus & $\begin{array}{l}\text { A molecule called ID-1, which was } \\
\text { significantly suppressed, } \\
\text { Down-regulation of ID-1 s was } \\
\text { dependent on NDRG-1/CAP43 }\end{array}$ & Anti-metastatic effect & [84] \\
\hline \multirow[t]{2}{*}{ Leukemia cells } & $\begin{array}{l}\text { NB4 } \\
\text { HL60 }\end{array}$ & Fucus vesiculosus & $\begin{array}{c}\text { Caspase- } 3,8,9 \uparrow \\
\text { PARP cleavage } \\
\text { Bax } \uparrow \\
\text { Activation of ERK1/2, AKT } \downarrow \\
\text { NK cell } \uparrow\end{array}$ & $\begin{array}{l}\text { Inhibits cell proliferation, } \\
\text { induces cell apoptosis }\end{array}$ & [85] \\
\hline & U937 & $\begin{array}{l}\text { Cladosiphon } \\
\text { okamuranus }\end{array}$ & $\begin{array}{l}\text { Apoptosis via caspase- } 3 \text { and }-7 \\
\text { activation-dependent pathway } \\
\text { PARP cleavage }\end{array}$ & $\begin{array}{l}\text { Inhibits cell proliferation, } \\
\text { induces cell apoptosis }\end{array}$ & [86] \\
\hline \multirow{4}{*}{ Lung cancer cells } & A549 & Undaria pinnatifida & $\begin{array}{c}\text { Bcl-2, p38, Phospho-PI3K/Akt, } \\
\text { procaspase-3 } \downarrow \\
\text { Bax, caspase-9, } \\
\text { Phospho-ERK1/2-MAPK } \uparrow \\
\text { PARP cleavage }\end{array}$ & $\begin{array}{l}\text { Inhibits cell proliferation, } \\
\text { induces cell apoptosis }\end{array}$ & [87] \\
\hline & NSCLC-N6 & Bifurcaria bifurcata & Irreversible growth arrest & Inhibits cell proliferation & [88] \\
\hline & $\begin{array}{l}\text { Lewis lung } \\
\text { carcinoma cells }\end{array}$ & Fucus vesiculosus & $\begin{array}{c}\text { PI3K-Akt-mTOR pathway } \downarrow \text { Caspase-3 } \uparrow \\
\text { Inhibition of VEGF, MMPs }\end{array}$ & $\begin{array}{l}\text { Inhibits metastasis and } \\
\text { induce apoptosis of } \\
\text { cancer cells }\end{array}$ & [89] \\
\hline & H1975 & Fucus vesiculosus & $\begin{array}{c}\text { Caspase- } 3 \uparrow \\
\text { PARP cleavage } \\
\text { TLR-4 mediated endoplasmic reticulum } \\
\text { stress }\end{array}$ & $\begin{array}{l}\text { Increases inhibition rate, } \\
\text { induces cell apoptosis }\end{array}$ & [90] \\
\hline
\end{tabular}

This table was modified and redrawn from Lin et al. 2020 [25].

\subsection{Effectiveness of Fucoidan against Colon Cancer}

Colon cancer is the most common form of cancer worldwide. When the human colon cancer DLD-1 model was administered with fucoidan extracted from brown alga Saccharina cichorioides, tumor cell proliferation was inhibited by the inhibition of the epidermal growth factor activity [76,91]. HT-29 and HCT116 cell lines undergo fucoidan-induced apoptosis, which is regulated by mitochondrial-mediated and receptor-mediated apoptotic pathways [69]. Thinh et al. reported three fucoidan fractions (SmF1, SmF2, and SmF3) extracted from Sargassum mcclurei where all fractions were found to be less cytotoxic and exhibited inhibition of colony formation in colon cancer DLD-1 cells [92]. HT-29 cell death is induced by administration of fucoidan, the probable reason for which could be the downregulation of IGF-IR signaling via the IRS-1/PI3K/AKT pathway [93].

Mice with colon tumors were administered low-, medium-, and high-molecularweight fucoidan. Medium-molecular-weight fucoidan was observed to significantly inhibit tumor growth. The results also showed that the survival time of mice in the fucoidantreated group was significantly higher than that of the mice in the control group, and there was a rapid increase in the number of NK cells in the spleen of the mice [27]. 


\subsection{Therapeutic Potential of Fucoidan against Breast Cancer}

Previous studies reported that apoptosis was induced by fucoidan in MCF-7 cells in a caspase-8-dependent pathway, along with chromatin condensation and nuclear DNA fragmentation $[78,94,95]$. When treated with fucoidan, T-47D cell proliferation was effectively inhibited and fucoidan posed very low toxicity to mouse epidermal cells [80]. MCF-7 cells treated with fucoidan from Undaria pinnatifida in New Zealand have been found to significantly suppress tumor cell proliferation with low cytotoxicity against normal tissue cells. The 3-[4,5 dimethylthiazol-2-yl]-2,5-di-diphenyltetrazolium bromide (MTT) method has been used by researchers to confirm the reduction in the number of viable cells by fucoidan [63]. The overall results of the respective study showed that fucoidan arrests the G1 phase by regulating apoptosis-related gene expression and the cell cycle. Fucoidan can effectively reverse the epithelial-mesenchymal transition (EMT) induced by TGF $\beta$ receptors (TGFR). This may lead to the upregulation and downregulation of epithelial and interstitial markers, respectively [96]. Fucoidan may inhibit the growth of MDA-MB-231 cells by reducing the expression of the transcriptional suppressors Snail, Slug, and Twist [96]. An in vivo study involving the administration of fucoidan to mice with 4T1 showed that the tumor volume was significantly reduced in the fucoidan-treated group compared with that of the control group injected with phosphate-buffered saline. This study showed that fucoidan effectively inhibited $4 \mathrm{~T} 1$ cell proliferation and metastasis [97]. Fucoidan, when combined with cisplatin, doxorubicin, and taxol, increased the cytotoxicity against MCF-7 breast cancer cells and thus it could be a promising compound in combination therapy [98]. Cladosiphon okamuranus extracted fucoidan in combination with coral-like Pt nanoparticles has proved to be a potential therapeutic agent against multidrug resistant breast cancer by multiple pathways such as anti-angiogenesis, interfering with metastasis, immune activation, and cell apoptosis [99].

\subsection{Protective Effect of Fucoidan on Hepatoma Cells}

Duan et al. showed that fucoidan plays a significant role in inhibiting cell proliferation in BEL-7402 and LM3 cell lines through the p38MAPK/ERK pathway [82]. Fucoidan administration results in the upregulation of NDRG-1/CAP43, mediated by the inhibition of hepatocarcinoma cells. Fucoidan may also lead to a reduction in hepatoma cell metastasis through the upregulation of p42/44 MAPK-mediated vacuolar membrane protein 1 (1VMP1), inhibition of caspases-7 and 8, and activation of the Fas-related death domain. Fucoidan showed antimetastatic activity in a MH134 cell model of liver metastasis [100].

Human hepatoma cells (SMMC-7721) exhibited significant growth inhibition and apoptosis induction following treatment with fucoidan. GSH consumption is associated with fucoidan-induced SMMC-7721 cell apoptosis. Treatment with fucoidan leads to increased levels of ROS in cells, along with mitochondrial damage and mitochondrial membrane potential (MMP) depolarization. Thus, the evidence clearly shows that fucoidan may induce apoptosis in human hepatocellular carcinoma SMMC-7721 cells via a ROSmediated mitochondrial pathway [83].

Few researchers have reported the upregulation of microRNA-29b (miR-29b) in human HCC and the inhibition of its downstream target DNA methyltransferase 3B (DNMT3B) by the administration of a fixed dose of fucoidan [101]. Inhibition of DNMT3B leads to suppression of mRNA and tumor metastasis suppressor gene 1 (MTSS1). In hepatoma cells, fucoidan administration may downregulate the transforming growth factor (TGF) receptor and SMAD signaling, which leads to the inhibition of extracellular matrix degradation and a reduction in the invasive activity of HCC cells [101,102].

\subsection{Fucoidan Exhibits Antileukemia Effects}

Various studies on the antileukemic effect of fucoidan have yielded good results, and researchers have investigated the signaling pathway for fucoidan-mediated apoptosis [103,104]. HL-60 cells treated with fucoidan showed the activation of caspases-3, -8 , and -9 and a change in the permeability of the mitochondrial membrane [85]. Mitogen- 
activated protein kinase p38 (MAPK) and the MAPK inhibitor p38 may be effectively activated by fucoidan [104]. Activation of p38 MAPK may play an important role in fucoidan-induced apoptosis. Moreover, the same study showed that increased apoptosis is associated with caspase hydrolases, Bid cleavage, Bax insertion into mitochondria, cytochrome c release from mitochondria, and membrane potential disruption in U937 cells [104].

Figure 2 depicts the fucoidan pathway in macrophage cells, which causes the generation of signaling proteins and further stimulates immune cells to destroy cancer cells.

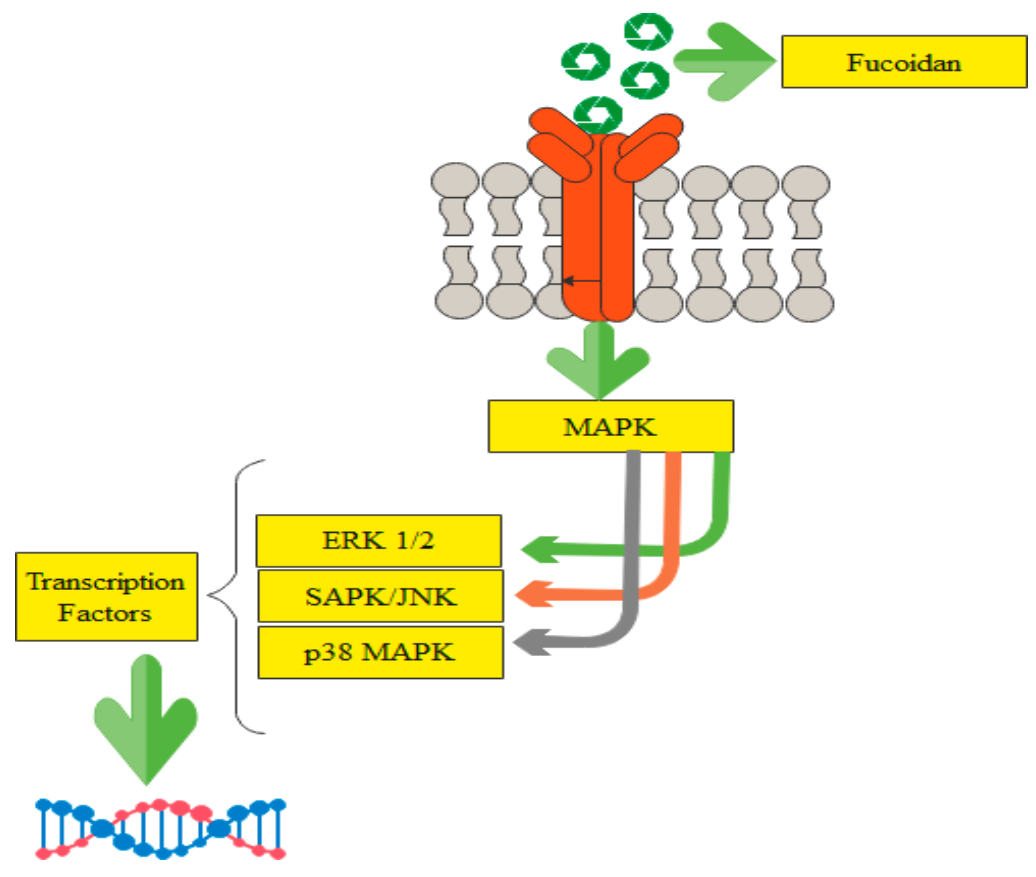

Figure 2. Fucoidan binds to specific types of receptors in macrophage cell membranes and activates MAPKs, which further prompt the activation of transcription factors, adapted from [25].

Researchers have investigated the cytotoxicity and antitumor activity of fucoidan in human acute myeloid leukemia cells [85,105]. The results of these analyses revealed that fucoidan significantly inhibits the proliferation and apoptosis of NB4 and HL60 cells by both endogenous and exogenous pathways [85].

In a study on NB4-transplanted mice, researchers observed that fucoidan can delay xenograft tumor growth and increase the cytolytic function of NK cells [85]. Researchers have also studied the anticancer activity of fucoidan in large B-cell lymphoma cells (DL$\mathrm{BCL}) ;[106]$ the results showed a loss of MMP in the lymphoma cells along with cytochrome $c$ release from their mitochondria and induction of lymphoma cell-specific apoptosis.

\subsection{Therapeutic Effects of Fucoidan against Human Bladder Cancer}

Reports have confirmed that some fucoidan-induced apoptosis effects have been observed after treatment with fucoidan, including mitochondrial dysfunction; increased Bax/Bcl-2 expression; Bid cleavage; Fas upregulation; sequential activation of caspases-8, 9, and 3; and decreased PARP degradation and IAP expression. Park et al. treated human bladder cancer cells with fucoidan and found that fucoidan inhibited tumor growth by enhancing the expression of cyclin-dependent kinase 1 inhibitors [107]. One another study reported the effect of fucoidan on bladder cancer cell growth by inducing G1 cell cycle arrest, which resulted in a reduced viability of EJ human bladder cancer cells [108]. The same group revealed that the fucoidan-induced arrest was associated with increased CDK inhibitor expression and the dephosphorylation of pRB. Other effects of fucoidan have also been reported, such as MMP loss and the release of cytochrome $\mathrm{c}$ from mitochondria to 
induce apoptosis $[95,104]$. These observations have shown that fucoidan plays an important role in the interaction between endogenous and exogenous caspase-dependent apoptotic pathways. Human telomerase reverse transcriptase enzyme, primary tumor transcription factor, and promotional protein 1 expression were reportedly reduced in fucoidan-treated human bladder cancer cells [109]. They also found that by inhibiting PI3K/Akt signaling pathway activation, fucoidan increases apoptosis and decreases telomerase activity, which is mediated by ROS-dependent PI3K/Akt pathway inactivation [109].

\subsection{Action of Fucoidan against Lung Cancer}

A previous study demonstrated that the administration of fucoidan led to an elevation of viral symptoms in C57BL/ 6 mice, which resulted in the inhibition of lung metastases in mice with transplanted Lewis lung cancer cells [110]. Previous studies have used C57BL/ 6 mice inoculated with Lewis lung cancer cells to investigate the combined effect of cyclophosphamide and fucoidan used as an adjuvant. The results obtained from the above experiment showed that repeated administration of fucoidan showed only an antimetastatic effect, and not an antitumor effect, with cyclophosphamide [24,111].

Moreau et al. found that when the human carcinoma line NSCLC-N6 was treated with fucoidan extracted from Bifurcaria bifurcate, cancer cells were irretrievably obstructed [88]. Fucoidan-treated A549 human lung cancer cells showed significant inhibition of tumor cell proliferation with low cytotoxicity against normal tissue [56]. Fucoidan from Undaria pinnatifida has been used for treating A549 cells, has antiproliferative activity, and regulates MAPK p38 [87]. Fucoidan extracted from Turbinaria conoides leads to a dose-dependent reduction in the survival rate of A549 cells, but it is not cytotoxic to a noncancerous human skin tissue keratinocyte (HaCaT) cell line [23].

Fucoidan combination therapy with anticancer drugs has been thoroughly reviewed by several researchers, and these reports have been found to be beneficial in terms of cancer prevention. Researchers have investigated the effect of fucoidan on sequential treatment (based on cisplatin), demonstrating that fucoidan upregulates the expression of cleaved caspase-3 and PARP [90]. A study in C57BL/ 6 mice transplanted with LLC-1 cells revealed that the combination of cisplatin and fucoidan was more effective in suppressing tumor volume than was the individual administration of each drug. In mice, fucoidan has been shown to suppress new blood vessels induced by sarcoma 180 cells [71]. The study demonstrated that fucoidan exhibited an effective antitumor effect owing to its antiangiogenic capacity. Qiu et al. investigated a combination study of fucoidan and gefitinib in tyrosine kinase inhibitor-resistant lung cancer cell lines by alleviating TGF-mediated slug expression, which was found to be a potent therapeutic approach. Previously, the combination of gefitinib and fucoidan significantly inhibited lung cancer cell viability by inducing an apoptotic response [112]. In another study, the combination treatment with GIV-A (fucoidan) and 5-FU significantly repressed the lung metastases. Furthermore, GIV-A improved the grade of spleen cell-mediated red blood cell hemolysis in sheep, indexes of the spleen and thymus, the number of spleen cells, and reinstated the 5-FU's suppressive effect. The study documented an alteration in the levels of Thy1.2-, L3T4- and asialo GM1-positive cells; activation of $\mathrm{C} 3$ and macrophages; and a lowering of the liver drug-metabolizing system [113].

\subsection{Fucoidan and Miscellaneous Cancer Therapies}

Oral administration of fucoidan $(5 \mathrm{mg} / \mathrm{kg})$ effectively inhibited tumor growth in mice grown with B16 melanoma cells. Oversulfated fucoidan has been found to suppress VEGF expression, inhibit neoplastic angiogenesis, and appears to be more effective than fucoidan [71]. Fucoidan-mediated treatment of the melanoma RPMI-7951 cell line has shown that fucoidan can regulate tumor cell turnover and affect tumor cell division [76]. PC-3, a human prostate cancer cell line, was cultured with fucoidan extracted from Undaria pinnatifida in a dose-dependent manner $(\mu \mathrm{g} / \mathrm{mL})$ [114]. Fucoidan administration led to the 
ERK1/2 MAPK-mediated inhibition of the p38 MAPK and PI3K/Akt signaling pathways, promoted PC-3 apoptosis, and protected against uncontrolled cancer division.

DU-145 cells were treated with fucoidan at a dose of 100-1000 $\mu \mathrm{g} / \mathrm{mL}$. Fucoidan inhibited the proliferation and functioning of DU-145 cells and the migration and processing of the cells in the matrix [73]. In an in vivo experiment, DU-145 cells were injected into mice to create cancer xenograft models [115].

Oral gavage at a dose of $20 \mathrm{mg} / \mathrm{kg}$ fucoidan for 28 days significantly suppressed tumor growth and angiogenesis, reduced hemoglobin content in tumor tissue, and decreased CD31 and CD105 mRNA expression [73]. In addition, activation of JAK, STAT3, VEGF, Bcl$\mathrm{kL}$, and cyclin D1 was significantly reduced after fucoidan treatment. Moreover, the results indicated that both the anticancer and anti-angiogenic effects of fucoidan could be mediated by JAK/STAT3 [73]. Hence, different doses and delivery routes may affect fucoidan metabolism in in vivo models and impact the possible treatment outcomes. Researchers have explored the potential mechanism of the antiproliferative effect of fucoidan on human gastric adenocarcinoma AGS cells [116]. The results showed that fucoidan can inhibit Bcl-2 and Bcl-xL expression and reduce MMP and the levels of protein polymerase (ADP-ribose). These data indicate that fucoidan can effectively inhibit AGS cell growth by stimulating autophagy and apoptosis. Bobiński et al. investigated activity of fucoidan on uterine sarcoma cell lines ESS-1 and MES-SA and the cancer cell lines SK-UT-1 and SK-UT-1B, and their toxic effects on human skin fibroblasts. The results showed that the viability of SK-UT-1, SK-UT-1B, and ESS1 cell lines was reduced following treatment with fucoidan, with no adverse effects on the proliferation of the adjacent non-cancer cells [117]. Thus, it was concluded that fucoidan not only affects cancer cell proliferation, but also potentially causes cytotoxic uterine cancer cell apoptosis.

There are various studies that explore the combined therapy of fucoidan with chemotherapy against different cancers. The fucoidan effects in combination with these drugs represent a novel approach for improving the side effects and ameliorating the immune response. The combined use of gemcitabine and cisplatin with low-molecular-weight fucoidan has been studied and showed an improvement of muscle atrophy in bladder cancer by inhibiting NF-kB mediated inflammation, activin A, and myostatin [118]. An another group investigated Undaria pinnatifida (UPF) or Fucus vesiculosus (FVF) in combination with paclitaxel and showed a possible antagonistic effect in breast cancer models (MCF-7 and ZR-75D) [119].

Fucoidan extracted from Cladosiphon okamuranus was administered in a combination treatment of chemotherapeutic drugs, namely oxaliplatin plus 5-fluorouracil/leucovorin (FOLFOX) or irinotecan plus 5-fluorouracil/leucovorin (FOLFIRI), and showed potential anticancer effects against recurrent colorectal cancer by lowering the cytotoxic effect of the chemotherapy drugs in patients, such as nausea, vomiting, stomatitis, diarrhea, liver dysfunction, etc. [120]. Further clinical trials and the development of fucoidan applications are required to address the safety concerns.

\section{Reports on Human Consumption of Fucoidan}

In recent years, there have been only a few studies on the possible systemic effects of oral fucoidan, and existing studies have mostly been conducted in mice. Few clinical studies on fucoidan have been reported because of the difficulty in ensuring the accuracy and representativeness of the study and quantifying the concentration of fucoidan in the body [17]. Fucoidan has not yet been approved as a medicinal product; therefore, large clinical trials cannot be performed.

By investigating many anticancer properties and mechanisms associated with fucoidan, researchers have found that its low toxicity and anti-inflammatory effects make it an ideal adjuvant therapeutic in the treatment of cancer. Hidenori et al. provided evidence that fucoidan acted as a potential anti-inflammatory agent in several patients with advanced cancer. Twenty patients with advanced cancer were selected for the study, in which oral fucoidan (4 $\mathrm{g}$ daily) was administered for at least four weeks. After two consecutive 
weeks of ingestion, there was a significant reduction in the levels of key proinflammatory cytokines, including interleukin 1-(IL-1 $\beta$ ), IL-6, and tumor necrosis factor alpha (TNF- $\alpha$ ), but no significant change was observed in patients' quality of life, including the experience of fatigue [121].

In a 12-week randomized, double-blind, controlled study in patients with osteoarthritis, treatment efficacy was measured by evaluating osteoarthritis severity, liver function, cholesterol levels, hematopoietic function, and renal function to determine the safety of fucoidan administration and to carefully monitor its side effects. The results showed that $300 \mathrm{mg}$ fucoidan is safe and well tolerated by humans [122]. However, the study reported that fucoidan did not significantly reduce the symptoms of osteoarthritis. In another study, researchers recruited 13 patients with HTLV-1-associated myelopathy/tropical spastic paralysis. The patients were administered $6 \mathrm{~g}$ fucoidan daily for 6 months. The associated results showed that previral DNA load in patients receiving fucoidan was significantly reduced by approximately $42.4 \%$ compared to that in the control group [123].

LMWF is a nutritional supplement that has been tested in patients with metastatic colorectal cancer as an adjunct to chemotherapy drugs and targeted drugs. The study was a double-blind, controlled trial involving approximately 54 patients. Twenty-eight subjects in the experimental group received $4 \mathrm{~g}$ fucoidan per day, and twenty-six subjects in the control group received $4 \mathrm{~g}$ cellulose per day. There was a significant difference in disease control rates between the experimental and control groups. This was the first clinical study to evaluate the effectiveness of LMWF as a supplemental therapy in patients with metastatic colorectal cancer [124].

A study was conducted in breast cancer patients to observe the effect of fucoidan derived from Undaria pinnatifida on the pharmacokinetics of hormone therapies such as those involving letrozole and tamoxifen. When patients were administered $1 \mathrm{~g}$ fucoidan daily for 3 weeks, the results revealed stable plasma concentrations of letrozole, tamoxifen, and the metabolites of tamoxifen after binding to fucoidan. Nevertheless, no significant difference in toxicity was observed during this period. These findings suggest that fucoidan can be used safely in conjunction with letrozole and tamoxifen [125].

Previous studies have asserted the pharmacokinetic properties of fucoidan by confirming its absorption using enzyme-linked immunosorbent assays (with specific antibodies) $[126,127]$. An observational study on healthy subjects who were administered or who consumed fucoidan showed that some amount of fucoidan was assimilated through endocytosis and could be detected in the blood and urine of the recruited subjects. Moreover, LMWF extracted from S. japonica resulted in both a higher absorption rate and bioavailability compared with those of the medium-molecular-weight fucoidan [128]. However, the biosafety and biodistribution of fucoidan still need to be explored further in humans.

\section{Possible Side Effects of Consuming Fucoidan}

Currently, there are very few studies on the side effects of fucoidan. Researchers have tested the toxicity of oral fucoidan in Sprague-Dawley rats. No major abnormalities in rat biomarkers were observed in mice administered $150-1350 \mathrm{mg} / \mathrm{kg}$ fucoidan daily for 28 days, and only female rats showed an increase in blood urea nitrogen [129]. Due to the adjuvant properties of fucoidan, it is used in combination therapy with anticancer drugs. Oh et al. reported that fucoidan alleviated the efficiency of lapitinib and exhibited antagonistic effects on the proliferation of some cancer cell lines [130]. In Ames tests, a concentration of $500 \mu \mathrm{L}$ fucoidan per plate showed no significant effect on the induction of colony growth. However, after taking $2000 \mathrm{mg} / \mathrm{kg}$ fucoidan daily, the rats exhibited an elevation of thyroid weight. Fat metabolism and alanine transaminase levels have been reported to significantly change in rats [131]. Li et al. revealed that daily administration of $300 \mathrm{mg} / \mathrm{kg} /$ body weight fucoidan extracted from Laminaria japonica to rats for over 180 days did not prompt any detrimental side effects; nonetheless, a higher dose of 900-2500 mg/mL caused coagulopathy and noticeably reduced blood clotting time [132]. A human study reported that 4 of 17 patients taking approximately $6 \mathrm{~g}$ fucoidan per day had diarrhea, and 
their condition was stable after discontinuing fucoidan intake. These findings suggest that fucoidan may be harmful to the liver. However, no significant research has been carried out, and it remains impossible to adequately assess the adverse effects of fucoidan [133]. Moreover, one case study suggested that one woman with excessive dietary intake of seaweeds or "Nori" had carotenodermia and an orange-yellow skin color [134].

\section{Conclusions}

Several studies have demonstrated the anticancer effect of fucoidan, including inhibition of the growth of various cancer cells, metastasis, angiogenesis, and induction of apoptosis in vitro and in vivo. Additionally, when administered with chemotherapy and radiotherapy drugs, fucoidan acts as an immunomodulatory molecule and reduces side effects, thus showing great potential in cancer treatment. However, because of the lack of information on drug interactions between fucoidan and conventional anticancer drugs, there is little clinical data on fucoidan.

More experimental studies are needed to explore the mechanisms involved in cancer treatment. Fucoidan may become an appropriate and natural therapeutic or adjunctive antitumor drug, providing new directions for the development of new anticancer drugs in the future.

Author Contributions: Conceptualized and writing, J.-O.J., P.S.C., D.Y.; Revision and editing, J.-O.J., D.Y., P.S.C.; contributed specialized sections, A.P.A., V.C. and A.D.; Supervision and resources, J.-O.J. All authors have read and agreed to the published version of the manuscript.

Funding: This study was supported by the National Research Foundation of Korea (NRF-2019R1C1C 1003334 and NRF-2020R1A6A1A03044512), the National Natural Science Foundation of China (81874164), and the National Research Foundation of Korea (NRF) funded by the Ministry of Education (NRF-2019R1G1A1008566).

Data Availability Statement: Not applicable.

Conflicts of Interest: The authors declare no conflict of interest.

\section{References}

1. Synytsya, A.; Kim, W.-J.; Kim, S.-M.; Pohl, R.; Synytsya, A.; Kvasnička, F.; Čopíková, J.; Park, Y.I. Structure and antitumour activity of fucoidan isolated from sporophyll of Korean brown seaweed Undaria pinnatifida. Carbohydr. Polym. 2010, 81, 41-48. [CrossRef]

2. Oliveira, C.; Neves, N.M.; Reis, R.L.; Martins, A.; Silva, T.H. A review on fucoidan antitumor strategies: From a biological active agent to a structural component of fucoidan-based systems. Carbohydr. Polym. 2020, 239, 116131. [CrossRef]

3. Costa, L.; Fidelis, G.; Cordeiro, S.L.; Oliveira, R.; Sabry, D.d.A.; Câmara, R.; Nobre, L.; Costa, M.; Almeida-Lima, J.; Farias, E. Biological activities of sulfated polysaccharides from tropical seaweeds. Biomed. Pharmacother. 2010, 64, 21-28. [CrossRef] [PubMed]

4. Dörschmann, P.; Bittkau, K.S.; Neupane, S.; Roider, J.; Alban, S.; Klettner, A. Effects of fucoidans from five different brown algae on oxidative stress and vegf interference in ocular cells. Mar. Drugs 2019, 17, 258. [CrossRef]

5. Garcia-Vaquero, M.; Ummat, V.; Tiwari, B.; Rajauria, G. Exploring ultrasound, microwave and ultrasound-microwave assisted extraction technologies to increase the extraction of bioactive compounds and antioxidants from brown macroalgae. Mar. Drugs 2020, 18, 172. [CrossRef]

6. Wang, Y.; Xing, M.; Cao, Q.; Ji, A.; Liang, H.; Song, S. Biological activities of fucoidan and the factors mediating its therapeutic effects: A review of recent studies. Mar. Drugs 2019, 17, 183. [CrossRef] [PubMed]

7. Ale, M.T.; Mikkelsen, J.D.; Meyer, A.S. Important determinants for fucoidan bioactivity: A critical review of structure-function relations and extraction methods for fucose-containing sulfated polysaccharides from brown seaweeds. Mar. Drugs 2011, 9, 2106-2130. [CrossRef]

8. Citkowska, A.; Szekalska, M.; Winnicka, K. Possibilities of fucoidan utilization in the development of pharmaceutical dosage forms. Mar. Drugs 2019, 17, 458. [CrossRef] [PubMed]

9. Pozharitskaya, O.N.; Obluchinskaya, E.D.; Shikov, A.N. Mechanisms of bioactivities of fucoidan from the brown seaweed fucus vesiculosus L. of the barents sea. Mar. Drugs 2020, 18, 275. [CrossRef]

10. Zayed, A.; Ulber, R. Fucoidans: Downstream processes and recent applications. Mar. Drugs 2020, 18, 170. [CrossRef]

11. Lin, H.-T.V.; Tsou, Y.-C.; Chen, Y.-T.; Lu, W.-J.; Hwang, P.-A. Effects of low-molecular-weight fucoidan and high stability fucoxanthin on glucose homeostasis, lipid metabolism, and liver function in a mouse model of type II diabetes. Mar. Drugs 2017, 15, 113. [CrossRef] [PubMed] 
12. Patel, S. Therapeutic importance of sulfated polysaccharides from seaweeds: Updating the recent findings. 3 Biotech 2012, 2, 171-185. [CrossRef]

13. Muhamad, I.I.; Zulkifli, N.; Lazim, N.A.M. Bioactive algal-derived polysaccharides: Multi-functionalization, therapeutic potential and biomedical applications. Curr. Pharm. Des. 2019, 25, 1147-1162. [CrossRef] [PubMed]

14. Salehi, B.; Sharifi-Rad, J.; Seca, A.M.L.; Pinto, D.C.G.A.; Michalak, I.; Trincone, A.; Mishra, A.P.; Nigam, M.; Zam, W.; Martins, N. Current trends on seaweeds: Looking at chemical composition, phytopharmacology, and cosmetic applications. Molecules 2019, 24, 4182. [CrossRef]

15. Li, J.; Guo, C.; Wu, J. Fucoidan: Biological activity in liver diseases. Am. J. Chin. Med. 2020, 48, 1617-1632. [CrossRef]

16. Dimitrova-Shumkovska, J.; Krstanoski, L.; Veenman, L. Potential beneficial actions of fucoidan in brain and liver injury, disease, and intoxication-potential implication of sirtuins. Mar. Drugs 2020, 18, 242. [CrossRef]

17. Luthuli, S.; Wu, S.; Cheng, Y.; Zheng, X.; Wu, M.; Tong, H. Therapeutic effects of fucoidan: A review on recent studies. Mar. Drugs 2019, 17, 487. [CrossRef]

18. Cunha, L.; Grenha, A. Sulfated seaweed polysaccharides as multifunctional materials in drug delivery applications. Mar. Drugs 2016, 14, 42. [CrossRef]

19. Li, B.; Lu, F.; Wei, X.; Zhao, R. Fucoidan: Structure and bioactivity. Molecules 2008, 13, 1671-1695. [CrossRef]

20. Reyes, M.E.; Riquelme, I.; Salvo, T.; Zanella, L.; Letelier, P.; Brebi, P. Brown seaweed fucoidan in cancer: Implications in metastasis and drug resistance. Mar. Drugs 2020, 18, 232. [CrossRef]

21. Cumashi, A.; Ushakova, N.A.; Preobrazhenskaya, M.E.; D’Incecco, A.; Piccoli, A.; Totani, L.; Tinari, N.; Morozevich, G.E.; Berman, A.E.; Bilan, M.I.; et al. A comparative study of the anti-inflammatory, anticoagulant, antiangiogenic, and antiadhesive activities of nine different fucoidans from brown seaweeds. Glycobiology 2007, 17, 541-552. [CrossRef] [PubMed]

22. Lahrsen, E.; Liewert, I.; Alban, S. Gradual degradation of fucoidan from Fucus vesiculosus and its effect on structure, antioxidant and antiproliferative activities. Carbohydr. Polym. 2018, 192, 208-216. [CrossRef] [PubMed]

23. Alwarsamy, M.; Gooneratne, R.; Ravichandran, R. Effect of fucoidan from Turbinaria conoides on human lung adenocarcinoma epithelial (a549) cells. Carbohydr. Polym. 2016, 152, 207-213. [CrossRef]

24. Alekseyenko, T.; Zhanayeva, S.Y.; Venediktova, A.; Zvyagintseva, T.; Kuznetsova, T.; Besednova, N.; Korolenko, T. Antitumor and antimetastatic activity of fucoidan, a sulfated polysaccharide isolated from the okhotsk sea Fucus evanescens brown alga. Bull. Exp. Biol. Med. 2007, 143, 730-732. [CrossRef] [PubMed]

25. Lin, Y.; Qi, X.; Liu, H.; Xue, K.; Xu, S.; Tian, Z. The anti-cancer effects of fucoidan: A review of both in vivo and in vitro investigations. Cancer Cell Int. 2020, 20, 154. [CrossRef]

26. Turner, P.V.; Brabb, T.; Pekow, C.; Vasbinder, M.A. Administration of substances to laboratory animals: Routes of administration and factors to consider. J. Am. Assoc. Lab. Anim. Sci. JAALAS 2011, 50, 600-613. [PubMed]

27. Azuma, K.; Ishihara, T.; Nakamoto, H.; Amaha, T.; Osaki, T.; Tsuka, T.; Imagawa, T.; Minami, S.; Takashima, O.; Ifuku, S. Effects of oral administration of fucoidan extracted from Cladosiphon okamuranus on tumor growth and survival time in a tumor-bearing mouse model. Mar. Drugs 2012, 10, 2337-2348. [CrossRef]

28. Manikandan, R.; Parimalanandhini, D.; Mahalakshmi, K.; Beulaja, M.; Arumugam, M.; Janarthanan, S.; Palanisamy, S.; You, S.; Prabhu, N.M. Studies on isolation, characterization of fucoidan from brown algae Turbinaria decurrens and evaluation of it's in vivo and in vitro anti-inflammatory activities. Int. J. Biol. Macromol. 2020, 160, 1263-1276. [CrossRef]

29. Zhang, W.; Park, H.-B.; Yadav, D.; Hwang, J.; An, E.-K.; Eom, H.-Y.; Kim, S.-J.; Kwak, M.; Lee, P.C.-W.; Jin, J.-O. Comparison of human peripheral blood dendritic cell activation by four fucoidans. Int. J. Biol. Macromol. 2021, 174, 477-484. [CrossRef]

30. Funt, S.A.; Patil, S.; Feldman, D.R.; Motzer, R.J.; Bajorin, D.F.; Sheinfeld, J.; Tickoo, S.K.; Reuter, V.E.; Bosl, G.J. Impact of teratoma on the cumulative incidence of disease-related death in patients with advanced germ cell tumors. J. Clin. Oncol. 2019, 37, 2329-2337. [CrossRef]

31. Galoczova, M.; Coates, P.; Vojtesek, B. Stat3, stem cells, cancer stem cells and p63. Cell. Mol. Biol. Lett. 2018, 23, 12. [CrossRef]

32. Ethun, C.G.; Bilen, M.A.; Jani, A.B.; Maithel, S.K.; Ogan, K.; Master, V.A. Frailty and cancer: Implications for oncology surgery, medical oncology, and radiation oncology. CA Cancer J. Clin. 2017, 67, 362-377. [CrossRef]

33. Mauguen, A.; Pignon, J.-P.; Burdett, S.; Domerg, C.; Fisher, D.; Paulus, R.; Mandrekar, S.J.; Belani, C.P.; Shepherd, F.A.; Eisen, T. Surrogate endpoints for overall survival in chemotherapy and radiotherapy trials in operable and locally advanced lung cancer: A re-analysis of meta-analyses of individual patients' data. Lancet Oncol. 2013, 14, 619-626. [CrossRef]

34. Im, J.H.; Seong, J.; Lee, I.J.; Park, J.S.; Yoon, D.S.; Kim, K.S.; Lee, W.J.; Park, K.R. Surgery alone versus surgery followed by chemotherapy and radiotherapy in resected extrahepatic bile duct cancer: Treatment outcome analysis of 336 patients. Cancer Res. Treat. 2016, 48, 583-595. [CrossRef]

35. Wong, R.S.Y. Apoptosis in cancer: From pathogenesis to treatment. J. Exp. Clin. Cancer Res. 2011, 30, 87. [CrossRef]

36. Henke, E.; Nandigama, R.; Ergün, S. Extracellular matrix in the tumor microenvironment and its impact on cancer therapy. Front. Mol. Biosci. 2020, 6, 160. [CrossRef] [PubMed]

37. Khan, M.; Maryam, A.; Qazi, J.I.; Ma, T. Targeting apoptosis and multiple signaling pathways with icariside ii in cancer cells. Int. J. Biol. Sci. 2015, 11, 1100-1112. [CrossRef]

38. Park, H.-B.; Lim, S.-M.; Hwang, J.; Zhang, W.; You, S.; Jin, J.-O. Cancer immunotherapy using a polysaccharide from codium fragile in a murine model. Oncoimmunology 2020, 9, 1772663. [CrossRef] [PubMed] 
39. Jin, J.O.; Zhang, W.; Du, J.Y.; Wong, K.W.; Oda, T.; Yu, Q. Fucoidan can function as an adjuvant in vivo to enhance dendritic cell maturation and function and promote antigen-specific $t$ cell immune responses. PLoS ONE 2014, 9, e99396. [CrossRef]

40. Ganesan, A.R.; Tiwari, U.; Rajauria, G. Seaweed nutraceuticals and their therapeutic role in disease prevention. Food Sci. Hum. Wellness 2019, 8, 252-263. [CrossRef]

41. Xu, L.; Zhang, W.; Zeng, L.; Jin, J.-O. Rehmannia glutinosa polysaccharide induced an anti-cancer effect by activating natural killer cells. Int. J. Biol. Macromol. 2017, 105, 680-685. [CrossRef] [PubMed]

42. Zhang, W.; Oda, T.; Yu, Q.; Jin, J.-O. Fucoidan from Macrocystis pyrifera has powerful immune-modulatory effects compared to three other fucoidans. Mar. Drugs 2015, 13, 1084-1104. [CrossRef] [PubMed]

43. Nagamine, T.; Kadena, K.; Tomori, M.; Nakajima, K.; Iha, M. Activation of nk cells in male cancer survivors by fucoidan extracted from Cladosiphon okamuranus. Mol. Clin. Oncol. 2020, 12, 81-88. [CrossRef] [PubMed]

44. Fitton, J.H.; Stringer, D.N.; Karpiniec, S.S. Therapies from fucoidan: An update. Mar. Drugs 2015, 13, 5920-5946. [CrossRef]

45. Catarino, M.D.; Silva, A.; Cardoso, S.M. Phycochemical constituents and biological activities of fucus spp. Mar. Drugs 2018, 16, 249. [CrossRef]

46. Phull, A.R.; Kim, S.J. Fucoidan as bio-functional molecule: Insights into the anti-inflammatory potential and associated molecular mechanisms. J. Funct. Foods 2017, 38, 415-426. [CrossRef]

47. Palacios-Gorba, C.; Pina, R.; Tortajada-Girbés, M.; Jiménez-Belenguer, A.; Siguemoto, É.; Ferrús, M.A.; Rodrigo, D.; Pina-Pérez, M.C. Caenorhabditis elegans as an in vivo model to assess fucoidan bioactivity preventing helicobacter pylori infection. Food Funct. 2020, 11, 4525-4534. [CrossRef]

48. Park, H.Y.; Han, M.H.; Park, C.; Jin, C.-Y.; Kim, G.-Y.; Choi, I.-W.; Kim, N.D.; Nam, T.-J.; Kwon, T.K.; Choi, Y.H. Anti-inflammatory effects of fucoidan through inhibition of $\mathrm{nf}-\mathrm{kb}$, mapk and akt activation in lipopolysaccharide-induced bv2 microglia cells. Food Chem. Toxicol. 2011, 49, 1745-1752. [CrossRef]

49. Van Weelden, G.; Bobiński, M.; Okła, K.; van Weelden, W.J.; Romano, A.; Pijnenborg, J.M.A. Fucoidan structure and activity in relation to anti-cancer mechanisms. Mar. Drugs 2019, 17, 32. [CrossRef]

50. Harden, E.A.; Falshaw, R.; Carnachan, S.M.; Kern, E.R.; Prichard, M.N. Virucidal activity of polysaccharide extracts from four algal species against herpes simplex virus. Antivir. Res. 2009, 83, 282-289. [CrossRef]

51. Sinha, S.; Astani, A.; Ghosh, T.; Schnitzler, P.; Ray, B. Polysaccharides from sargassum tenerrimum: Structural features, chemical modification and anti-viral activity. Phytochemistry 2010, 71, 235-242. [CrossRef]

52. Hsu, H.-Y.; Hwang, P.-A. Clinical applications of fucoidan in translational medicine for adjuvant cancer therapy. Clin. Transl. Med. 2019, 8, 15. [CrossRef]

53. Liu, S.; Yang, J.; Peng, X.; Li, J.; Zhu, C. The natural product fucoidan inhibits proliferation and induces apoptosis of human ovarian cancer cells: Focus on the pi3k/akt signaling pathway. Cancer Manag. Res. 2020, 12, 6195. [CrossRef] [PubMed]

54. Zhang, Z.; Teruya, K.; Yoshida, T.; Eto, H.; Shirahata, S. Fucoidan extract enhances the anti-cancer activity of chemotherapeutic agents in mda-mb-231 and mcf-7 breast cancer cells. Mar. Drugs 2013, 11, 81-98. [CrossRef]

55. You, S.; Yang, C.; Lee, H.; Lee, B.-Y. Molecular characteristics of partially hydrolyzed fucoidans from sporophyll of undaria pinnatifida and their in vitro anticancer activity. Food Chem. 2010, 119, 554-559. [CrossRef]

56. Mak, W.; Wang, S.K.; Liu, T.; Hamid, N.; Li, Y.; Lu, J.; White, W.L. Anti-proliferation potential and content of fucoidan extracted from sporophyll of new zealand undaria pinnatifida. Front. Nutr. 2014, 1, 9. [CrossRef]

57. Li, J.; Chen, K.; Li, S.; Liu, T.; Wang, F.; Xia, Y.; Lu, J.; Zhou, Y.; Guo, C. Pretreatment with fucoidan from fucus vesiculosus protected against cona-induced acute liver injury by inhibiting both intrinsic and extrinsic apoptosis. PLoS ONE 2016, 11, e0152570. [CrossRef] [PubMed]

58. Zayed, A.; Hahn, T.; Finkelmeier, D.; Burger-Kentischer, A.; Rupp, S.; Krämer, R.; Ulber, R. Phenomenological investigation of the cytotoxic activity of fucoidan isolated from Fucus vesiculosus. Process Biochem. 2019, 81, 182-187. [CrossRef]

59. Zayed, A.; El-Aasr, M.; Ibrahim, A.-R.S.; Ulber, R. Fucoidan characterization: Determination of purity and physicochemical and chemical properties. Mar. Drugs 2020, 18, 571. [CrossRef] [PubMed]

60. Bittkau, K.S.; Dörschmann, P.; Blümel, M.; Tasdemir, D.; Roider, J.; Klettner, A.; Alban, S. Comparison of the effects of fucoidans on the cell viability of tumor and non-tumor cell lines. Mar. Drugs 2019, 17, 441. [CrossRef] [PubMed]

61. Zhang, F.; Shi, J.-J.; Thakur, K.; Hu, F.; Zhang, J.-G.; Wei, Z.-J. Anti-cancerous potential of polysaccharide fractions extracted from peony seed dreg on various human cancer cell lines via cell cycle arrest and apoptosis. Front. Pharmacol. 2017, 8, 102. [CrossRef]

62. Aquib, M.; Farooq, M.A.; Filli, M.S.; Boakye-Yiadom, K.O.; Kesse, S.; Maviah, M.B.J.; Mavlyanova, R.; Wang, B. A review on the chemotherapeutic role of fucoidan in cancer as nanomedicine. Res. J. Life Sci. Bioinform. Pharm. Chem. Sci. 2019, 5, 512-539.

63. Lu, J.; Shi, K.K.; Chen, S.; Wang, J.; Hassouna, A.; White, L.N.; Merien, F.; Xie, M.; Kong, Q.; Li, J. Fucoidan extracted from the new zealand Undaria pinnatifida - physicochemical comparison against five other fucoidans: Unique low molecular weight fraction bioactivity in breast cancer cell lines. Mar. Drugs 2018, 16, 461. [CrossRef] [PubMed]

64. Ponce, N.M.A.; Stortz, C.A. A comprehensive and comparative analysis of the fucoidan compositional data across the phaeophyceae. Front. Plant Sci. 2020, 11. [CrossRef] [PubMed]

65. Krylova, N.V.; Ermakova, S.P.; Lavrov, V.F.; Leneva, I.A.; Kompanets, G.G.; Iunikhina, O.V.; Nosik, M.N.; Ebralidze, L.K.; Falynskova, I.N.; Silchenko, A.S. The comparative analysis of antiviral activity of native and modified fucoidans from brown algae Fucus evanescens in vitro and in vivo. Mar. Drugs 2020, 18, 224. [CrossRef] 
66. Fitton, J.H.; Stringer, D.N.; Park, A.Y.; Karpiniec, S.S. Therapies from fucoidan: New developments. Mar. Drugs 2019, $17,571$. [CrossRef]

67. Wu, S.Y.; Yang, W.Y.; Cheng, C.C.; Lin, K.H.; Sampurna, B.P.; Chan, S.M.; Yuh, C.H. Low molecular weight fucoidan inhibits hepatocarcinogenesis and nonalcoholic fatty liver disease in zebrafish via asgr/stat3/hnf4a signaling. Clin. Transl. Med. 2020, 10, e252. [CrossRef] [PubMed]

68. Bae, H.; Lee, J.-Y.; Yang, C.; Song, G.; Lim, W. Fucoidan derived from Fucus vesiculosus inhibits the development of human ovarian cancer via the disturbance of calcium homeostasis, endoplasmic reticulum stress, and angiogenesis. Mar. Drugs 2020, 18, 45. [CrossRef]

69. Kim, E.J.; Park, S.Y.; Lee, J.-Y.; Park, J.H.Y. Fucoidan present in brown algae induces apoptosis of human colon cancer cells. BMC Gastroenterol. 2010, 10, 96. [CrossRef] [PubMed]

70. Chen, M.C.; Hsu, W.L.; Hwang, P.A.; Chou, T.C. Low molecular weight fucoidan inhibits tumor angiogenesis through downregulation of hif-1/vegf signaling under hypoxia. Mar. Drugs 2015, 13, 4436-4451. [CrossRef] [PubMed]

71. Koyanagi, S.; Tanigawa, N.; Nakagawa, H.; Soeda, S.; Shimeno, H. Oversulfation of fucoidan enhances its anti-angiogenic and antitumor activities. Biochem. Pharmacol. 2003, 65, 173-179. [CrossRef]

72. Chen, L.-M.; Liu, P.-Y.; Chen, Y.-A.; Tseng, H.-Y.; Shen, P.-C.; Hwang, P.-A.; Hsu, H.-L. Oligo-fucoidan prevents il-6 and ccl2 production and cooperates with p53 to suppress atm signaling and tumor progression. Sci. Rep. 2017, 7, 11864. [CrossRef]

73. Rui, X.; Pan, H.F.; Shao, S.L.; Xu, X.M. Anti-tumor and anti-angiogenic effects of fucoidan on prostate cancer: Possible jak-stat3 pathway. BMC Complement. Altern. Med. 2017, 17, 378. [CrossRef]

74. Zorofchian Moghadamtousi, S.; Karimian, H.; Khanabdali, R.; Razavi, M.; Firoozinia, M.; Zandi, K.; Abdul Kadir, H. Anticancer and antitumor potential of fucoidan and fucoxanthin, two main metabolites isolated from brown algae. Sci. World J. 2014, 2014, 768323. [CrossRef] [PubMed]

75. Atashrazm, F.; Lowenthal, R.M.; Woods, G.M.; Holloway, A.F.; Dickinson, J.L. Fucoidan and cancer: A multifunctional molecule with anti-tumor potential. Mar. Drugs 2015, 13, 2327-2346. [CrossRef]

76. Vishchuk, O.S.; Ermakova, S.P.; Zvyagintseva, T.N. The fucoidans from brown algae of far-eastern seas: Anti-tumor activity and structure-function relationship. Food Chem. 2013, 141, 1211-1217. [CrossRef]

77. Han, Y.S.; Lee, J.H.; Lee, S.H. Fucoidan inhibits the migration and proliferation of ht-29 human colon cancer cells via the phosphoinositide-3 kinase/akt/mechanistic target of rapamycin pathways. Mol. Med. Rep. 2015, 12, 3446-3452. [CrossRef] [PubMed]

78. Yamasaki-Miyamoto, Y.; Yamasaki, M.; Tachibana, H.; Yamada, K. Fucoidan induces apoptosis through activation of caspase-8 on human breast cancer mcf-7 cells. J. Agric. Food Chem. 2009, 57, 8677-8682. [CrossRef] [PubMed]

79. He, X.; Xue, M.; Jiang, S.; Li, W.; Yu, J.; Xiang, S. Fucoidan promotes apoptosis and inhibits emt of breast cancer cells. Biol. Pharm. Bull. 2019, 42, 442-447. [CrossRef] [PubMed]

80. Vishchuk, O.S.; Tarbeeva, D.V.; Ermakova, S.P.; Zvyagintseva, T.N. Structural characteristics and biological activity of fucoidans from the brown algae Alaria sp. and Saccharina japonica of different reproductive status. Chem. Biodivers. 2012, 9, 817-828. [CrossRef]

81. Zhang, Z.; Teruya, K.; Eto, H.; Shirahata, S. Induction of apoptosis by low-molecular-weight fucoidan through calcium- and caspase-dependent mitochondrial pathways in mda-mb-231 breast cancer cells. Biosci. Biotechnol. Biochem. 2013, 77, 235-242 [CrossRef]

82. Duan, Y.; Li, J.; Jing, X.; Ding, X.; Yu, Y.; Zhao, Q. Fucoidan induces apoptosis and inhibits proliferation of hepatocellular carcinoma via the p38 mapk/erk and pi3k/akt signal pathways. Cancer Manag. Res. 2020, 12, 1713-1723. [CrossRef]

83. Yang, L.; Wang, P.; Wang, H.; Li, Q.; Teng, H.; Liu, Z.; Yang, W.; Hou, L.; Zou, X. Fucoidan derived from Undaria pinnatifida induces apoptosis in human hepatocellular carcinoma smmc-7721 cells via the ros-mediated mitochondrial pathway. Mar. Drugs 2013, 11, 1961-1976. [CrossRef]

84. Cho, Y.; Cho, E.J.; Lee, J.H.; Yu, S.J.; Kim, Y.J.; Kim, C.Y.; Yoon, J.H. Fucoidan-induced id-1 suppression inhibits the in vitro and in vivo invasion of hepatocellular carcinoma cells. Biomed. Pharmacother. 2016, 83, 607-616. [CrossRef]

85. Atashrazm, F.; Lowenthal, R.M.; Woods, G.M.; Holloway, A.F.; Karpiniec, S.S.; Dickinson, J.L. Fucoidan suppresses the growth of human acute promyelocytic leukemia cells in vitro and in vivo. J. Cell. Physiol. 2016, 231, 688-697. [CrossRef] [PubMed]

86. Teruya, T.; Konishi, T.; Uechi, S.; Tamaki, H.; Tako, M. Anti-proliferative activity of oversulfated fucoidan from commercially cultured Cladosiphon okamuranus tokida in u937 cells. Int. J. Biol. Macromol. 2007, 41, 221-226. [CrossRef] [PubMed]

87. Boo, H.-J.; Hyun, J.-H.; Kim, S.-C.; Kang, J.-I.; Kim, M.-K.; Kim, S.-Y.; Cho, H.; Yoo, E.-S.; Kang, H.-K. Fucoidan from undaria pinnatifida induces apoptosis in a549 human lung carcinoma cells. Phytother. Res. 2011, 25, 1082-1086. [CrossRef] [PubMed]

88. Moreau, D.; Thomas-Guyon, H.; Jacquot, C.; Jugé, M.; Culioli, G.; Ortalo-Magné, A.; Piovetti, L.; Roussakis, C. An extract from the brown alga Bifurcaria bifurcata induces irreversible arrest of cell proliferation in a non-small-cell bronchopulmonary carcinoma line. J. Appl. Phycol. 2006, 18, 87-93. [CrossRef]

89. Han, Y.-S.; Lee, J.H.; Chang, H.S.; Lee, S.H. Inhibition of lewis lung cancer cell growth and migration by fucoidan. Mol. Cell. Toxicol. 2014, 10, 269-276. [CrossRef]

90. Hsu, H.Y.; Lin, T.Y.; Hu, C.H.; Shu, D.T.F.; Lu, M.K. Fucoidan upregulates tlr4/chop-mediated caspase-3 and parp activation to enhance cisplatin-induced cytotoxicity in human lung cancer cells. Cancer Lett. 2018, 432, 112-120. [CrossRef] 
91. Usoltseva, R.V.; Shevchenko, N.M.; Malyarenko, O.S.; Anastyuk, S.D.; Kasprik, A.E.; Zvyagintsev, N.V.; Ermakova, S.P. Fucoidans from brown algae Laminaria longipes and Saccharina cichorioides: Structural characteristics, anticancer and radiosensitizing activity in vitro. Carbohydr. Polym. 2019, 221, 157-165. [CrossRef]

92. Thinh, P.D.; Menshova, R.V.; Ermakova, S.P.; Anastyuk, S.D.; Ly, B.M.; Zvyagintseva, T.N. Structural characteristics and anticancer activity of fucoidan from the brown alga Sargassum mcclurei. Mar. Drugs 2013, 11, 1456-1476. [CrossRef]

93. Kim, I.-H.; Nam, T.-J. Fucoidan downregulates insulin-like growth factor-i receptor levels in ht-29 human colon cancer cells. Oncol. Rep. 2018, 39, 1516-1522. [CrossRef]

94. Mooney, L.; Al-Sakkaf, K.; Brown, B.; Dobson, P. Apoptotic mechanisms in t47d and mcf-7 human breast cancer cells. Br. J. Cancer 2002, 87, 909-917. [CrossRef]

95. Zhang, Z.; Teruya, K.; Eto, H.; Shirahata, S. Fucoidan extract induces apoptosis in mcf-7 cells via a mechanism involving the ros-dependent jnk activation and mitochondria-mediated pathways. PLoS ONE 2011, 6, e27441. [CrossRef]

96. Hsu, H.-Y.; Lin, T.-Y.; Hwang, P.-A.; Tseng, L.-M.; Chen, R.-H.; Tsao, S.-M.; Hsu, J. Fucoidan induces changes in the epithelial to mesenchymal transition and decreases metastasis by enhancing ubiquitin-dependent $\operatorname{tg} \mathrm{f} \beta$ receptor degradation in breast cancer. Carcinogenesis 2012, 34, 874-884. [CrossRef]

97. Xue, M.; Ge, Y.; Zhang, J.; Wang, Q.; Hou, L.; Liu, Y.; Sun, L.; Li, Q. Anticancer properties and mechanisms of fucoidan on mouse breast cancer in vitro and in vivo. PLoS ONE 2012, 7, e43483. [CrossRef]

98. Abudabbus, A.; Badmus, J.A.; Shalaweh, S.; Bauer, R.; Hiss, D. Effects of fucoidan and chemotherapeutic agent combinations on malignant and non-malignant breast cell lines. Curr. Pharm. Biotechnol. 2017, 18, 748-757. [CrossRef]

99. Kang, S.; Kang, K.; Chae, A.; Kim, Y.K.; Jang, H.; Min, D.H. Fucoidan-coated coral-like pt nanoparticles for computed tomographyguided highly enhanced synergistic anticancer effect against drug-resistant breast cancer cells. Nanoscale 2019, 11, 15173-15183. [CrossRef]

100. Cho, Y.; Yoon, J.-H.; Yoo, J.-j.; Lee, M.; Lee, D.H.; Cho, E.J.; Lee, J.-H.; Yu, S.J.; Kim, Y.J.; Kim, C.Y. Fucoidan protects hepatocytes from apoptosis and inhibits invasion of hepatocellular carcinoma by up-regulating p42/44 mapk-dependent ndrg-1/cap43. Acta Pharm. Sin. B 2015, 5, 544-553. [CrossRef]

101. Yan, M.D.; Yao, C.J.; Chow, J.M.; Chang, C.L.; Hwang, P.A.; Chuang, S.E.; Whang-Peng, J.; Lai, G.M. Fucoidan elevates microrna$29 \mathrm{~b}$ to regulate dnmt3b-mtss1 axis and inhibit emt in human hepatocellular carcinoma cells. Mar. Drugs 2015, 13, 6099-6116. [CrossRef]

102. Yan, B.; Guo, Q.; Fu, F.J.; Wang, Z.; Yin, Z.; Wei, Y.B.; Yang, J.R. The role of mir-29b in cancer: Regulation, function, and signaling. Onco Targets Ther. 2015, 8, 539-548. [CrossRef] [PubMed]

103. Jin, J.O.; Song, M.G.; Kim, Y.N.; Park, J.I.; Kwak, J.Y. The mechanism of fucoidan-induced apoptosis in leukemic cells: Involvement of erk1/2, jnk, glutathione, and nitric oxide. Mol. Carcinog. 2010, 49, 771-782. [CrossRef] [PubMed]

104. Park, H.S.; Hwang, H.J.; Kim, G.Y.; Cha, H.J.; Kim, W.J.; Kim, N.D.; Yoo, Y.H.; Choi, Y.H. Induction of apoptosis by fucoidan in human leukemia u937 cells through activation of p38 mapk and modulation of bcl-2 family. Mar. Drugs 2013, 11, 2347-2364. [CrossRef]

105. Wei, C.; Xiao, Q.; Kuang, X.; Zhang, T.; Yang, Z.; Wang, L. Fucoidan inhibits proliferation of the skm-1 acute myeloid leukaemia cell line via the activation of apoptotic pathways and production of reactive oxygen species. Mol. Med. Rep. 2015, 12, 6649-6655. [CrossRef] [PubMed]

106. Yang, G.; Zhang, Q.; Kong, Y.; Xie, B.; Gao, M.; Tao, Y.; Xu, H.; Zhan, F.; Dai, B.; Shi, J.; et al. Antitumor activity of fucoidan against diffuse large b cell lymphoma in vitro and in vivo. Acta Biochim. Biophys. Sin. 2015, 47, 925-931. [CrossRef]

107. Park, H.Y.; Kim, G.Y.; Moon, S.K.; Kim, W.J.; Yoo, Y.H.; Choi, Y.H. Fucoidan inhibits the proliferation of human urinary bladder cancer $\mathrm{t} 24$ cells by blocking cell cycle progression and inducing apoptosis. Molecules 2014, 19, 5981-5998. [CrossRef]

108. Park, H.Y.; Choi, I.-W.; Kim, G.-Y.; Kim, B.W.; Kim, W.-J.; Choi, Y.H. Fucoidan induces g1 arrest of the cell cycle in ej human bladder cancer cells through down-regulation of prb phosphorylation. Rev. Bras. Farmacogn. 2015, 25, 246-251. [CrossRef]

109. Han, M.H.; Lee, D.S.; Jeong, J.W.; Hong, S.H.; Choi, I.W.; Cha, H.J.; Kim, S.; Kim, H.S.; Park, C.; Kim, G.Y. Fucoidan induces ros-dependent apoptosis in 5637 human bladder cancer cells by downregulating telomerase activity via inactivation of the pi3k/akt signaling pathway. Drug Dev. Res. 2017, 78, 37-48. [CrossRef]

110. Huang, T.-H.; Chiu, Y.-H.; Chan, Y.-L.; Chiu, Y.-H.; Wang, H.; Huang, K.-C.; Li, T.-L.; Hsu, K.-H.; Wu, C.-J. Prophylactic administration of fucoidan represses cancer metastasis by inhibiting vascular endothelial growth factor (vegf) and matrix metalloproteinases (mmps) in lewis tumor-bearing mice. Mar. Drugs 2015, 13, 1882-1900. [CrossRef]

111. Vo, T.-S.; Kim, S.-K. Fucoidans as a natural bioactive ingredient for functional foods. J. Funct. Foods 2013, 5, 16-27. [CrossRef]

112. Qiu, W.L.; Tseng, A.J.; Hsu, H.Y.; Hsu, W.H.; Lin, Z.H.; Hua, W.J.; Lin, T.Y. Fucoidan increased the sensitivity to gefitinib in lung cancer cells correlates with reduction of tgf $\beta$-mediated slug expression. Int. J. Biol. Macromol. 2020, 153, 796-805. [CrossRef] [PubMed]

113. Itoh, H.; Noda, H.; Amano, H.; Ito, H. Immunological analysis of inhibition of lung metastases by fucoidan (giv-a) prepared from brown seaweed sargassum thunbergii. Anticancer Res. 1995, 15, 1937-1947.

114. Boo, H.J.; Hong, J.Y.; Kim, S.C.; Kang, J.I.; Kim, M.K.; Kim, E.J.; Hyun, J.W.; Koh, Y.S.; Yoo, E.S.; Kwon, J.M.; et al. The anticancer effect of fucoidan in pc-3 prostate cancer cells. Mar. Drugs 2013, 11, 2982-2999. [CrossRef] 
115. Yang, X.; Wang, S.; Trangle, S.S.; Li, Y.; White, W.L.; Li, J.; Ying, T.; Kong, Q.; Zhao, Y.; Lu, J. Investigation of different molecular weight fucoidan fractions derived from new zealand Undaria pinnatifida in combination with groa therapy in prostate cancer cell lines. Mar. Drugs 2018, 16, 454. [CrossRef]

116. Park, H.S.; Kim, G.Y.; Nam, T.J.; Deuk Kim, N.; Hyun Choi, Y. Antiproliferative activity of fucoidan was associated with the induction of apoptosis and autophagy in ags human gastric cancer cells. J. Food Sci. 2011, 76, T77-T83. [CrossRef] [PubMed]

117. Bobiński, M.; Okła, K.; Bednarek, W.; Wawruszak, A.; Dmoszyńska-Graniczka, M.; Garcia-Sanz, P.; Wertel, I.; Kotarski, J. The effect of fucoidan, a potential new, natural, anti-neoplastic agent on uterine sarcomas and carcinosarcoma cell lines: Enitec collaborative study. Arch. Immunol. Ther. Exp. 2019, 67, 125-131. [CrossRef]

118. Chen, M.C.; Hsu, W.L.; Hwang, P.A.; Chen, Y.L.; Chou, T.C. Combined administration of fucoidan ameliorates tumor and chemotherapy-induced skeletal muscle atrophy in bladder cancer-bearing mice. Oncotarget 2016, 7, 51608-51618. [CrossRef] [PubMed]

119. Burney, M.; Mathew, L.; Gaikwad, A.; Nugent, E.K.; Gonzalez, A.O.; Smith, J.A. Evaluation fucoidan extracts from Undaria pinnatifida and Fucus vesiculosus in combination with anticancer drugs in human cancer orthotopic mouse models. Integr. Cancer Ther. 2018, 17, 755-761. [CrossRef]

120. Ikeguchi, M.; Yamamoto, M.; Arai, Y.; Maeta, Y.; Ashida, K.; Katano, K.; Miki, Y.; Kimura, T. Fucoidan reduces the toxicities of chemotherapy for patients with unresectable advanced or recurrent colorectal cancer. Oncol. Lett. 2011, 2, 319-322. [CrossRef]

121. Takahashi, H.; Kawaguchi, M.; Kitamura, K.; Narumiya, S.; Kawamura, M.; Tengan, I.; Nishimoto, S.; Hanamure, Y.; Majima, Y.; Tsubura, S. An exploratory study on the anti-inflammatory effects of fucoidan in relation to quality of life in advanced cancer patients. Integr. Cancer Ther. 2018, 17, 282-291. [CrossRef] [PubMed]

122. Myers, S.P.; Mulder, A.M.; Baker, D.G.; Robinson, S.R.; Rolfe, M.I.; Brooks, L.; Fitton, J.H. Effects of fucoidan from fucus vesiculosus in reducing symptoms of osteoarthritis: A randomized placebo-controlled trial. Biol. Targets Ther. 2016, 10, 81.

123. Araya, N.; Takahashi, K.; Sato, T.; Nakamura, T.; Sawa, C.; Hasegawa, D.; Ando, H.; Aratani, S.; Yagishita, N.; Fujii, R.; et al. Fucoidan therapy decreases the proviral load in patients with human t-lymphotropic virus type-1-associated neurological disease. Antivir. Ther. 2011, 16, 89-98. [CrossRef] [PubMed]

124. Tsai, H.-L.; Tai, C.-J.; Huang, C.-W.; Chang, F.-R.; Wang, J.-Y. Efficacy of low-molecular-weight fucoidan as a supplemental therapy in metastatic colorectal cancer patients: A double-blind randomized controlled trial. Mar. Drugs 2017, 15, 122. [CrossRef] [PubMed]

125. Tocaciu, S.; Oliver, L.J.; Lowenthal, R.M.; Peterson, G.M.; Patel, R.; Shastri, M.; McGuinness, G.; Olesen, I.; Fitton, J.H. The effect of Undaria pinnatifida fucoidan on the pharmacokinetics of letrozole and tamoxifen in patients with breast cancer. Integr. Cancer Ther. 2018, 17, 99-105. [CrossRef]

126. Irhimeh, M.R.; Fitton, J.H.; Lowenthal, R.M.; Kongtawelert, P. A quantitative method to detect fucoidan in human plasma using a novel antibody. Methods Find. Exp. Clin. Pharmacol. 2005, 27, 705-710. [CrossRef]

127. Torode, T.A.; Marcus, S.E.; Jam, M.; Tonon, T.; Blackburn, R.S.; Hervé, C.; Knox, J.P. Monoclonal antibodies directed to fucoidan preparations from brown algae. PLoS ONE 2015, 10, e0118366. [CrossRef]

128. Matsubara, K.; Xue, C.; Zhao, X.; Mori, M.; Sugawara, T.; Hirata, T. Effects of middle molecular weight fucoidans on in vitro and ex vivo angiogenesis of endothelial cells. Int. J. Mol. Med. 2005, 15, 695-699. [CrossRef]

129. Kim, K.J.; Lee, O.H.; Lee, H.H.; Lee, B.Y. A 4-week repeated oral dose toxicity study of fucoidan from the sporophyll of undaria pinnatifida in sprague-dawley rats. Toxicology 2010, 267, 154-158. [CrossRef]

130. Oh, B.; Kim, J.; Lu, W.; Rosenthal, D. Anticancer effect of fucoidan in combination with tyrosine kinase inhibitor lapatinib. Evid. Based Complement. Alternat. Med. 2014, 2014, 865375. [CrossRef]

131. Chung, H.J.; Jeun, J.; Houng, S.J.; Jun, H.J.; Kweon, D.K.; Lee, S.J. Toxicological evaluation of fucoidan from Undaria pinnatifidain vitro and in vivo. Phytother. Res. 2010, 24, 1078-1083. [CrossRef] [PubMed]

132. Li, N.; Zhang, Q.; Song, J. Toxicological evaluation of fucoidan extracted from Laminaria japonica in wistar rats. Food Chem. Toxicol. 2005, 43, 421-426. [CrossRef] [PubMed]

133. Wang, Y.-Q.; Wei, J.-G.; Tu, M.-J.; Gu, J.-G.; Zhang, W. Fucoidan alleviates acetaminophen-induced hepatotoxicity via oxidative stress inhibition and nrf2 translocation. Int. J. Mol. Sci. 2018, 19, 4050. [CrossRef] [PubMed]

134. Nishimura, Y.; Ishii, N.; Sugita, Y.; Nakajima, H. A case of carotenodermia caused by a diet of the dried seaweed called nori. J. Dermatol. 1998, 25, 685-687. [CrossRef] [PubMed] 